\title{
Mengenal Lebih Dalam Marketing Plan
}

\author{
Andini Galuh Priyani \\ Program Studi Kewirausahaan \\ Universitas Bina Nusantara \\ andini.priyani@binus.ac.id
}

Marketing Plan atau rencana pemasaran ialah metode yang digunakan oleh perusahaan untuk memperkenalkan serta menyampaikan produk atau jasa seperti apa yang akan dipasarkan kepada calon pasar. Kewirausahaan membutuhkan pemasaran yang efektif dan efisien. Marketing plan berisi uraian strategi pemasaran yang akan diambil serta dijalankan oleh perusahaan dengan mempertimbangkan hasil dan resiko yang akan didapat selama periode tertentu. Membuat marketing plan tidak membutuhkan pengeluaran yang banyak serta waktu yang lama, hanya saja yang dibutuhkan dalam pembuatan marketing plan adalah penelitian atau analisis yang sesuai dan akurat serta usaha. Berikut beberapa jenis dari marketing plan.

1. Pemasaran berbayar: menampilkan iklan lalu berbayar per klik.

2. Pemasaran media social: memanfaatkan media sosial seperti Instagram, Twitter, Facebook, dll.

3. Pemasaran periode waktu: kampanye yang dilakukan selama periode yang sudah ditentukan.

4. Pemasaran konten: membuat konten yang menampilkan produk atau jasa yang akan ditawarkan

5. Pemasaran produk atau jasa baru: merencanakan peluncuran produk/jasa baru.

Marketing plan yang efektif ialah rencana yang dibuat dapat membantu perusahaan untuk memahami target pasar yang akan dituju, memahami kompetitor, memahami dampak dan resiko dari hasil keputusan yang sudah dipilih, bisa memberi gambaran untuk perusahaan dalam jangka waktu yang panjang. Perusahaan perlu kembangkan pemasaran secara digital di era pasar berbasis digital. Perusahaan tidak bisa mengembangkan marketing plan jika tidak melakukan riset pasar, karena dari riset pasar ini perusahaan dapat lebih terarah dalam berupaya untuk menentukan stretagi pemasaran apa yang akan diambil, dari riset pasar ini perusahaan bisa mendapatkan informasi seputar target pasar dan yang terakhir yaitu bisa mengetahui kelayakan produk atau jasa yang akan dipasarkan. Hal-hal yang akan dilakukan jika perusahaan melakukan riset pasar:

1. Memantau apa yang sedang trend di dalam industri dan ekonomi.

2. Memantau kompetitor supaya perusahaan dapat melihat perkembangan serta dapat memperoleh keunggulan dari segi penetapan harga dan pelayanan. 
3. Menentukan cara yang terbaik untuk menjangkau target pasar melalui berbagai macam bentuk iklan (iklan tradisional, sosial media, dan saluran iklan lainnya).

Marketing plan memiliki berbagai macam variasi sesuai dengan apa yang bisnis inginkan. Mulai dari industri, jenis produk atau jasa, tujuan yang diingkan oleh perusahaan. Tetapi masih ada elemen-elemen penting yang termasuk juga dalam marketing plan, yaitu:

1. Ringkasan eksekutif dan deskripsi bisnis.

2. Analisis situasi.

3. Tujuan pemasaran dan tujuan bisnis.

4. Target pasar.

5. Strategi penjualan yang unik.

6. Anggaran.

7. Evaluasi.

\section{References}

Barringer, B. R. (2015). Preparing Effective Business Plans: An Entrepreneurial Approach (2nd ed.). Pearson Education Limited. https://bookshelf.vitalsource.com/reader/books/9781292059679/pageid/1

Chen, J. (2021). Marketing Plan. Investopedia.

https://www.investopedia.com/terms/m/marketing-plan.asp

Lake, L. (2020). What Is a Marketing Plan. September, 17. Dotdash.

https://www.thebalancesmb.com/what-is-a-marketing-plan-2295831

Saputra, D. H., Sutiksno, D. U., Kusuma, A. H. P., Romindo, Wahyuni, D., Purnomo, A., \& Simarmata, J. (2020). Digital Marketing: Komunikasi Bisnis Menjadi Lebih Mudah. Yayasan Kita Menulis.

\section{Biografi}

\section{Andini Galuh Priyani}

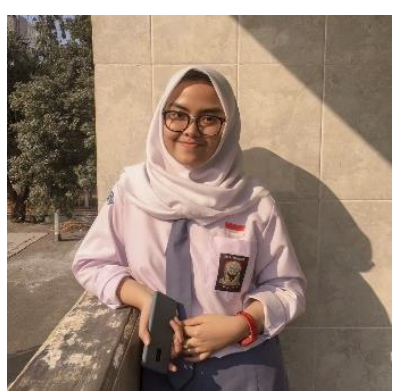

Penulis kelahiran Malang ini adalah seorang mahasiswa program studi kewirausahaan di Universitas Bina Nusantara, kampus Malang sejak tahun 2020. Andin sedang menjalankan rintisan wirausaha Love by Nature yang bergerak di bidang fashion. Penggemar lagu religi yang diiringi alat music hadroh dan warna merah muda memiliki prinsip hidup bahwa "Hidup itu dijalani bukan direnungi" .

Email: andini.priyani@binus.ac.id Instagram: @andiiingp 